\title{
Gorlin-Goltz Syndrome: A Rare Case Report of a 11-Year-Old Child
}

\author{
${ }^{1}$ Sandeep Tandon, ${ }^{2}$ Yashwant Chauhan, ${ }^{3}$ Meenakshi Sharma, ${ }^{4}$ Manish Jain
}

\begin{abstract}
Gorlin-Goltz Syndrome, also known as nevoid basal cell carcinoma syndrome (NBCCS), is an autosomal dominant trait caused due to mutations in the patched tumor suppressor gene $(\mathrm{PTCH})$ gene found on the long arm of chromosome 9. The syndrome is characterized by the presence of odontogenic keratocysts (OKCs), basal cell carcinomas, and skeletal malformations. Early diagnosis of the syndrome can be done by pedodontist as OKC is one of the early manifestations of the syndrome. Early diagnosis and treatment is important for long-term prognosis of the syndrome by reducing the severity of cutaneous carcinomas and deformities due to jaw cyst. The present case describes an 11-year-old patient with some typical features of NBCCS, which were diagnosed through its oral and maxillofacial manifestations. This case emphasizes the importance of pedodontist in early recognition of the syndrome.
\end{abstract}

Keywords: Gorlin-Goltz syndrome, Nevoid basal cell carcinoma, Odontogenic keratocysts.

How to cite this article: Tandon S, Chauhan Y, Sharma M, Jain M. Gorlin-Goltz Syndrome: A Rare Case Report of a 11-Year-Old Child. Int J Clin Pediatr Dent 2016;9(3):264-268.

\section{Source of support: Nil}

Conflict of interest: None

\section{INTRODUCTION}

Gorlin-Goltz syndrome or nevoid basal cell carcinoma syndrome (NBCCS) was described by Gorlin and Goltz in $1960 .^{1}$ It is an autosomal dominant disorder with a high degree of penetrance and variable expressivity. ${ }^{2}$ The incidence of this disorder is estimated to be 1 in 50,000 to 150,000 in general population, varying by region. ${ }^{3}$ However, individual features of this disorder have been described for centuries with the first evidence in historical

\footnotetext{
${ }^{1}$ Senior Professor and Head, ${ }^{2}$ Postgraduate Student, ${ }^{3}$ Senior Lecturer, ${ }^{4}$ Associate Professor

${ }^{1-3}$ Department of Pedodontics and Preventive Dentistry, RUHS College of Dental Sciences, Jaipur, Rajasthan, India

${ }^{4}$ Department of Oral Pathology, NIMS Dental College, Jaipur Rajasthan, India

Corresponding Author: Meenakshi Sharma, Senior Lecturer Department of Pedodontics and Preventive Dentistry, RUHS College of Dental Sciences, Jaipur, Rajasthan, India, Phone: +919461011234, e-mail: dr.mesharma@gmail.com
}

document from ancient Egypt. The syndrome was first described by Jarish and White in 1894 as they noticed the presence of multiple basocellular carcinoma, and then in 1960 Gorlin and Goltz described classical triad of multiple basocellular epithilioma, keratocyst in jaw, and bifid rib, which was later on modified by Rayner et al ${ }^{4}$ in 1977, who established that for diagnosis at least cyst had to appear in combination with calcification of the falx cerebri or palmer and planter pits.

Pathogenesis of NBCCS is due to mutations in the patched tumor suppressor gene (PTCH) on chromosome 9q21-23 where abnormality in the Hedgehog ( $\mathrm{Hh}$ ) signaling pathway results in neoplasm formation. ${ }^{5}$

Early diagnosis of the syndrome is of great clinical importance since severity of complications, such as maxilloacial deformities related to the jaw cyst can be avoided and long-term prognosis of malignant skin lesion and brain tumor is better when early diagnosis and treatment can be initiated. ${ }^{6}$

The present case describes a patient with some typical features of NBCCS, which were diagnosed for the first time in our department. Furthermore, the case emphasizes the importance of pedodontist in early recognition of the syndrome.

\section{CASE REPORT}

An 11-year-old young patient reported to Department of Pedodontics and Preventive Dentistry, Government Dental College and Hospital, Jaipur, Rajasthan, India, with chief complaint of slowly growing swelling on right lower posterior side of face for 3 months. Swelling was associated with dull pain which was localized, and not with ulceration, inflammation, or paresthesia.

Patient had natal history of birth hypoxia with hypoxic ischemic encephalopathy (HIE) which was resolved after 1 year according to computed tomography (CT) report, and the patient's mother was operated for odontogenic keratocyst (OKC).

On extraoral clinical examination, a hard, tender swelling of about $3.5 \times 3 \mathrm{~cm}$ with ill-defined borders on right mandibular premolar region was present. There was no lymphadenopathy (Fig. 1).

Intraorally, the swelling was associated with expansion of buccal cortical plate with obliteration of vestibule 


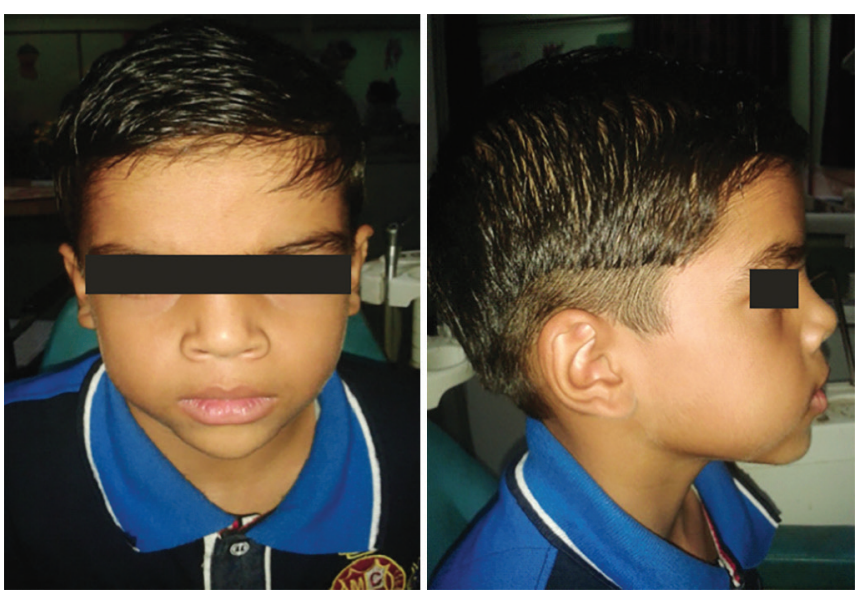

Fig. 1: Preoperative frontal and lateral profile of patient

adjacent to right lower first molar and egg shell crackling. There was no mobility or pain on percussion of associated teeth. The left-side extra- and intraoral examination did not revealed any significant details.

On radiographic examination, orthopantomography (OPG) showed bilateral, well-defined radiolucencies surrounded by corticated, scalloped radiopaque borders giving multilocular appearance (Fig. 2).

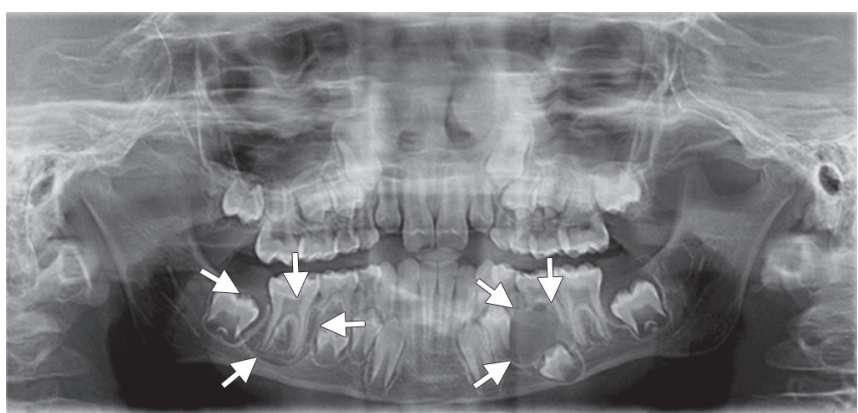

Fig. 2: Preoperative OPG showing bilateral OKCs in posterior mandible

Computed tomography images revealed abnormal multilocular, expansile, cystic lesion with a bony sclerotic margin (Fig. 3). Owing to the presence of bilateral cystic swelling in mandible, Gorlin-Goltz syndrome was suspected and further investigations were carried out.

Computed tomography/radiograph report of our case revealed:

- Bilateral OKCs in mandibular molar region

- Calcification of falx cerebri

- Chest radiograph bifid rib was present (Figs 4 and 5)
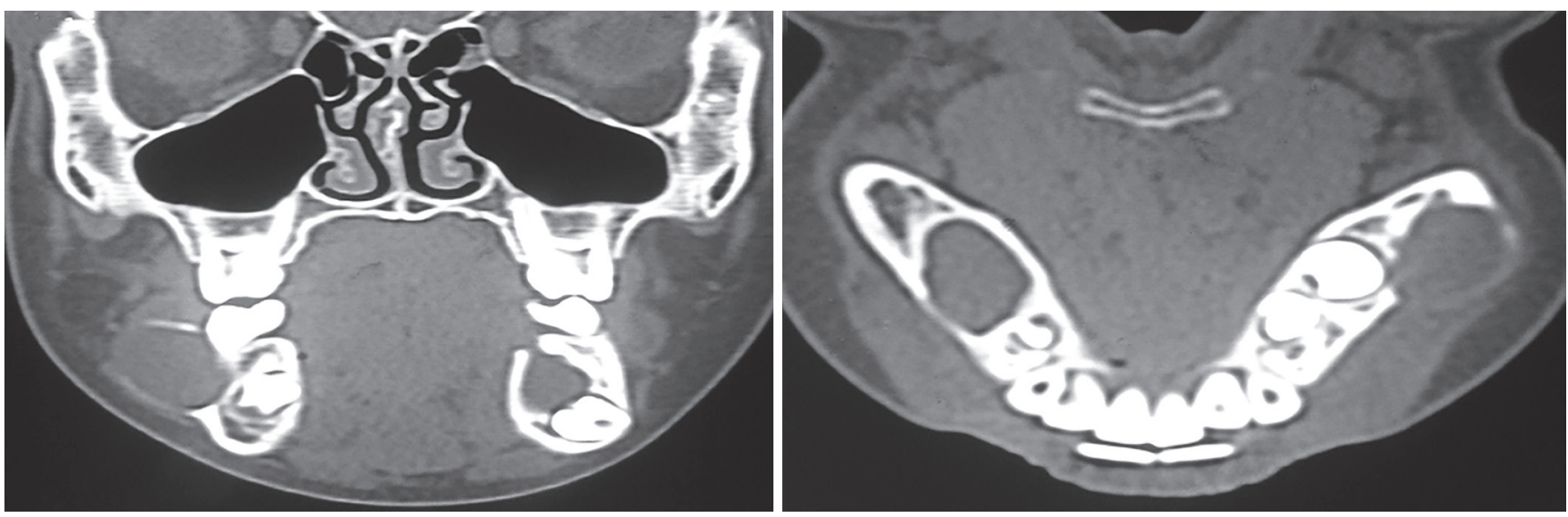

Fig. 3: Computed tomography mandible showing bilateral OKCs
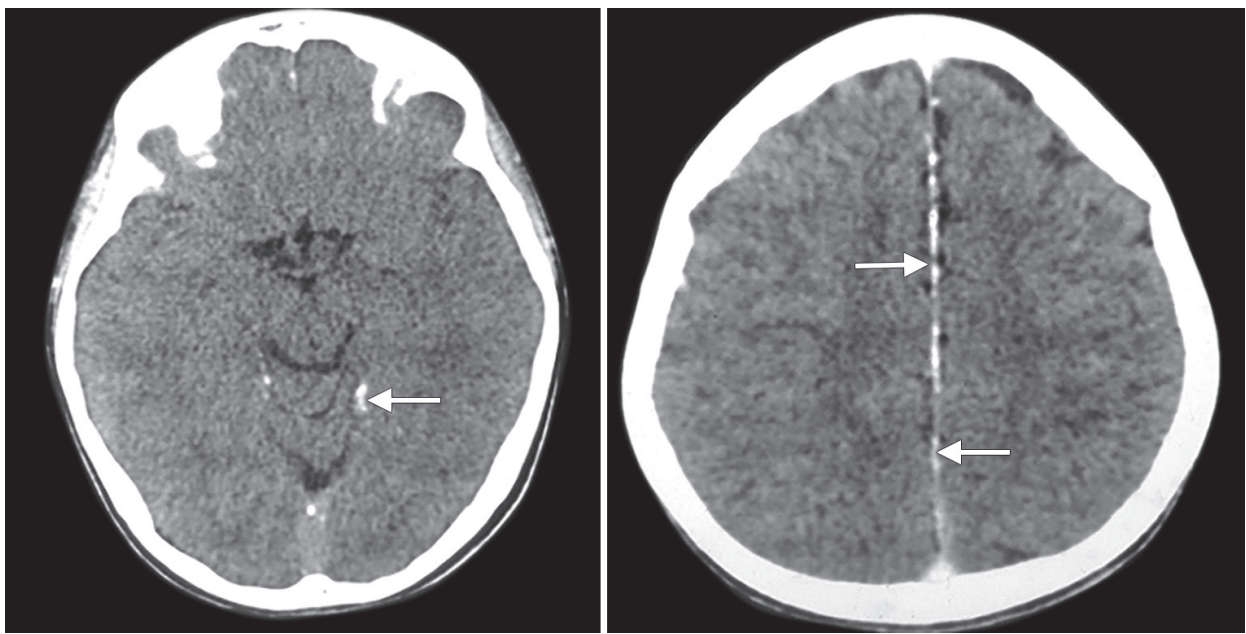

Fig. 4: Computed tomography brain showing calcification of falx cerebri and tentorium 


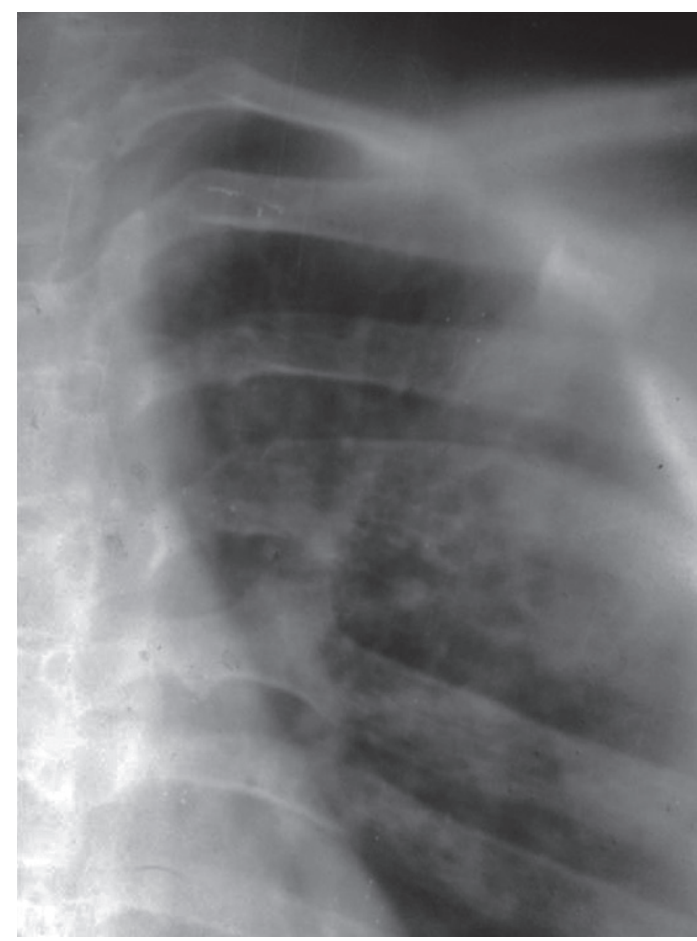

Fig. 5: Chest radiograph showing unilateral bifid 5th rib

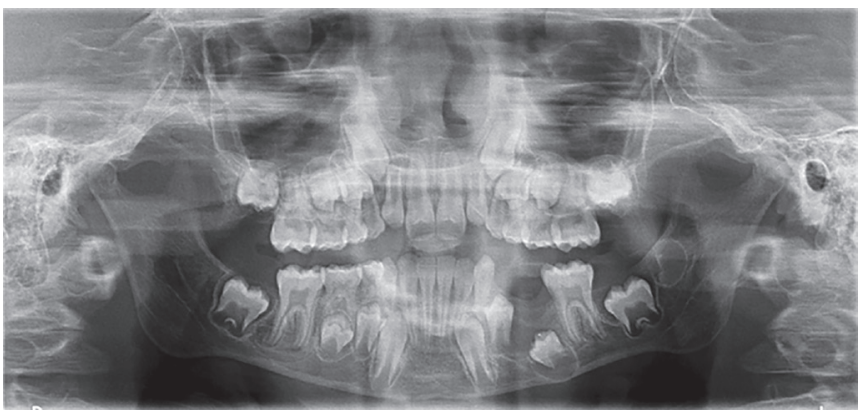

Fig. 8: Orthopantomography at 3-month follow-up

The case is diagnosed using diagnostic protocol of Lo Muzio. ${ }^{7}$ Treatment plan included enucleation under general anesthesia.

- Procedure on right side - enucleation followed by primary closure.

- Procedure on left side - enucleation with fenestration or open packing with iodoform gauge, after extraction of 74 and 75 (Fig. 6).

Histopathologically the report showed parakeratinized stratified epithelium with an average thickness of 5 to 8 cells, with basal cells fenced up in a corrugated surface and a connective wall rich in mucopolisacarides and with a variable number of microcysts and epithelial islets seen. This confirmed the OKCs on both sides (Fig. 7).

The patient was on regular follow-up (Fig. 8). Lingual arch space maintainer was given for smooth eruption of 34 and 35 (Fig. 9).

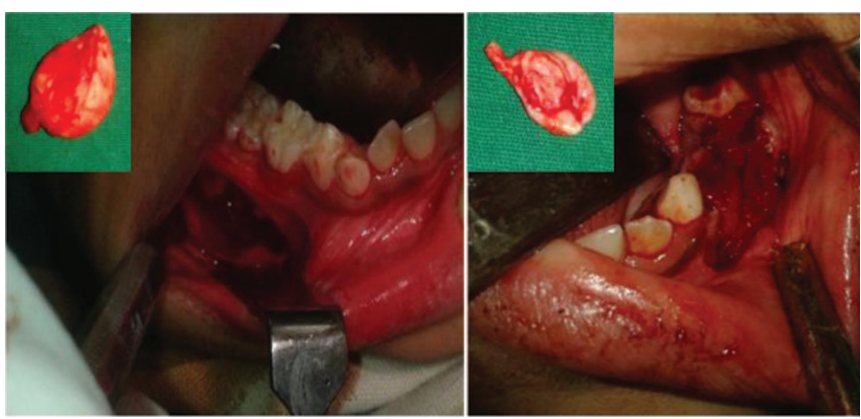

Fig. 6: Intraoperative view with enucleated cysts

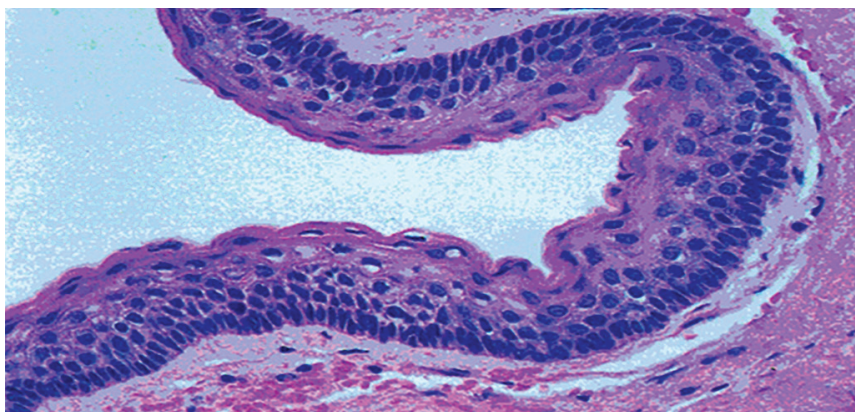

Fig. 7: Micrograph of OKC showing hyperchromatism and pallisading appearance

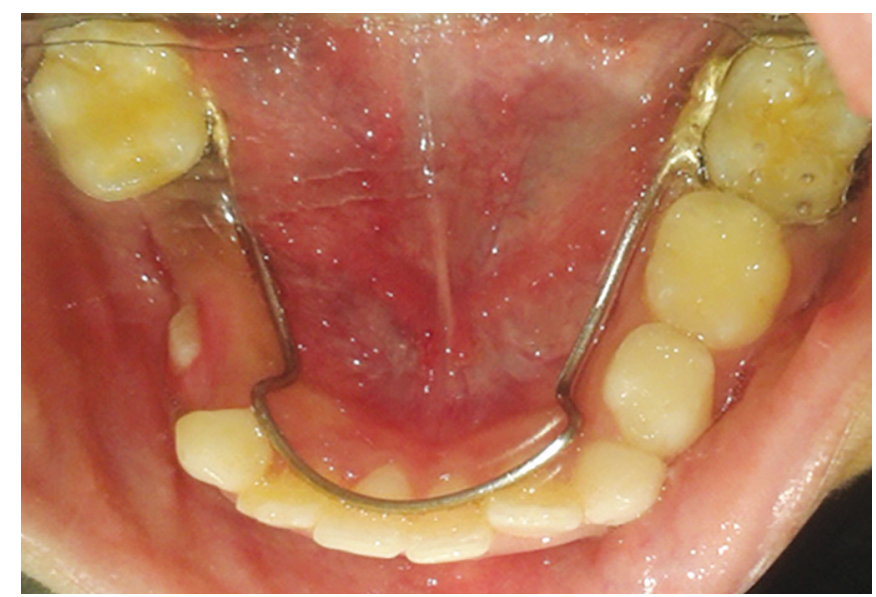

Fig. 9: Mandibular occlusal view with lingual arch space maintainer

\section{DISCUSSION}

Diagnostic criteria for NBCCS was established by Evans et $\mathrm{al}^{8},{ }^{8}$ modified by Kimonis et al, ${ }^{9}$ reviewed by Manfredi et $\mathrm{al}^{10}{ }^{10}$ and more recently, a multi disciplinary colloquium was organized to better define the physical findings associated with NBCCS. The participants reviewed the diagnostic criteria of the syndrome, and there was no consensus for a formal recommendation. Consequently, a suspected diagnosis of NBCCS should be considered based on findings of less stringent criteria:

- One major criterion and molecular confirmation

- Two major criteria

- One major and two minor criteria 
Table 1: Major and minor criteria stated by first international colloquium on NBCCS

\begin{tabular}{|c|c|c|}
\hline Sl. no. & Major criteria & Minor criteria \\
\hline 1 & $\begin{array}{l}\text { Basal cell carcinoma (BCC) prior to } 20 \text { years old or excessive number } \\
\text { of BCC out of proportion to prior sun exposure and skin type }\end{array}$ & Rib anomalies \\
\hline 2 & Odontogenic keratocyst of jaw prior to 20 years of age & Macrocephaly determined after adjustment for height \\
\hline 3 & Palmer or planter pitting & $\begin{array}{l}\text { Other specific skeletal malformation and radiologic } \\
\text { changes (i.e., vertebral anomalies, kyphoscoliosis, } \\
\text { short fourth metacarpals, past axial polyductyly) }\end{array}$ \\
\hline 4 & Lamellar calcification of the falx cerebri & Cleft lip/palate \\
\hline 5 & Medulloblastoma, typically desmoplastic & Ovarian/cardiac fibroma \\
\hline \multirow[t]{2}{*}{6} & First degree in relation to NBCCS & Lymphomesentric cysts \\
\hline & & $\begin{array}{l}\text { Ocular abnormalities (i.e., strasbismus, hypertelorism, } \\
\text { congenital cataract, glaucoma, coloboma) }\end{array}$ \\
\hline
\end{tabular}

Major and minor criteria stated by first international colloquium on NBCCS (see Bree et $\mathrm{al}^{11}$ ) is given in Table 1.

In this case, we found two major criteria, i.e., histologically proven OKCs bilaterally in molar region of mandible, calcification of falx cerebri in CT report, and one minor criterion, i.e., unilateral 5 th bifid rib. So, this case fits into criteria of Gorlin-Goltz syndrome.

Odontogenic keratocysts are most frequently observed and usually the first manifestation of NBCCS, so they often occur in the early decades of life ${ }^{12,13}$ and have high recurrence rate and tendency toward multiplicity, particularly when associated with NBCCS. ${ }^{13}$ Odontogenic keratocysts, found in posterior molar region of mandible, were supported by studies done by Woolgar et $\mathrm{al}^{14}$ The posterior area of mandible was the main affected site, followed by maxillary molar region. Moreover, OKCs were bilateral (i.e., two in number) which were supported by studies by Ahn et al, ${ }^{15}$ who found 1 to 6 OKCs associated with NBCCS cases, and by Gupta et $\mathrm{al}^{16}$ who found in a series of case reports six Indian patients, all developed multiple OKCs (ranges from 3-6).

Treatment of OKCs by enucleation may be considered adequate provided that all teeth included within or in contact with the lesion are extracted. However, this treatment can be combined with fenestration or open packing as required depending on size of the lesion and patient's age. In particular, if the patient is in the first or second decade of life with hitherto unerupted permanent teeth involving OKCs, it would be difficult to make a decision regarding aggressive surgery. Some authors describe how aggressive surgery can have adverse effect on dental development of the affected jaw. ${ }^{17}$ Therefore, in this case, conservative treatment was chosen as on right-side enucleation with closure by suture and on leftside enucleation with fenestration or open packing with iodoform gauge. Also, patients suffering from NBCCS have to undergo checkups at least once a year, especially those having OKCs. ${ }^{18}$

In NBCCS in the skull, there is early onset of calcification with lamellar calcification of falx cerebri up to 70 to
$85 \%$, calcification of tentorium cerebelli up to $20 \%$, and dura and choroids. ${ }^{19}$ In this case also, calcification of falx cerebri and tentorium was observed in CT report.

$\mathrm{Rib}$ anomaly found in this case was consistent with findings from Shanley et $\mathrm{al}^{20}$ and Kimonis et al. ${ }^{9}$

As the name of syndrome is NBCCS, no BCC was found. This can be explained with the help of the studies done by Endo et $\mathrm{al}^{21}$ and Ahn et $\mathrm{al}^{15}$ that BCC prevalence seems to be low in Asia, and BCC proliferates between puberty and 35 years of age. ${ }^{22}$ Because, in this case, the patient is 11 years old, we suggest continuous monitoring as there may be possibility of BCC occurrence in future.

The guidelines for follow-up of NBCCS as given by de Amezaga et $\mathrm{al}^{6}$ should be followed:

- Neurological examination - twice yearly

- Cerebral MRI - once in year for 1 to 7 years of age

- Skin examination - yearly

- Cardiologic examination - according to sign and symptoms

- Genetic counseling of families as it is an autosomal dominant disorder.

\section{CONCLUSION}

This case shows the importance of awareness of this rare syndrome in young people without any skin lesions. Early diagnosis of syndrome and a long follow-up period is important due to the severity of clinical manifestation. Moreover, a multidisciplinary team is required, including dentist, dermatologist, geneticists, and neurologist, so that there are increased chances of better overall survival rates. So Gorlin-Goltz syndrome was diagnosed and treated for one of its major anomalies, i.e., OKCs, whereas the other anomalies did not require active management at this stage. Lingual arch space maintainer was given for smooth eruption of 34 and 35.

\section{REFERENCES}

1. Gorlin RJ, Goltz RW. Multiple nevoid basal-cell epithelioma, jaw cysts and bifid rib. A syndrome. N Engl J Med 1960 May;262:908-912. 
2. Gorlin RJ. Nevoid basal-cell carcinoma syndrome. Medicine 1987 Mar;66(2):98-113.

3. Patil K, Mahima VG, Gupta B. Gorlin syndrome: a case report. J Indian Soc Pedod Prev Dent 2005 Oct-Dec;23(4):198-203.

4. Rayner CR, Towers JF, Wilson JS. What is Gorlin's syndrome? The diagnosis and management of the basal cell naevus syndrome, based on a study of thirty-seven patients. Br J Plast Surg 1977 Jan;30(1):62-67.

5. Ljubenovic M, Ljubenovic D, Binic I, Jovanovic D, Stanojevic M. Gorlin-Goltz syndrome. Acta Dermatovenerol Alp Panonica Adriat 2007 Dec;16(4):166-169.

6. de Amezaga AOG, Arregui OG, Nuño SZ, Sagredo AA, Urizar JMA. Gorlin-Goltz syndrome: clinicopathologic aspects. Med Oral Patol Oral Cir Bucal 2008 Jun 1;13(6):E338-E343.

7. Lo Muzio L. Nevoid basal cell carcinoma syndrome (Gorlin syndrome). Orphanet J Rare Dis 2008 Nov 25;3:32.

8. Evans DG, Ladusans EJ, Rimmer S, Burnell LD, Thakker N, Farndon PA. Complications of the naevoid basal cell carcinoma syndrome: results of a population based study. J Med Genet 1993 Jun;30(6):460-464.

9. Kimonis VE, Goldstein AM, Pastakia B, Yang ML, Kase R, DiGiovanna JJ, Bale AE, Bale SJ. Clinical manifestations in 105 persons with nevoid basal cell carcinoma syndrome. Am J Med Genet 1997 Mar 31;69(3):299-308.

10. Manfredi M, Vescovi P, Bonanini M, Porter S. Nevoid basal cell carcinoma syndrome: a review of the literature. Int J Oral Maxillofac Surg 2004 Mar;33(2):117-124.

11. Bree AF, Shah MR, BCNS Colloquium Group. Consensus statement from the first international colloquium on basal cell nevus syndrome (BCNS). Am J Med Genet A 2011 Sep;155A(9):2091-2097.

12. Casaroto AR, Loures DC, Moreschi E, Veltrini VC, Trento CL, Gottardo VD, Lara VS. Early diagnosis of Gorlin-Goltz syndrome: case report. Head Face Med 2011 Jan 25;7:1-5.

13. Barnes L, Eveson JW, Reichart P, Sidransky D. World Health Organization classification of tumors. Pathology and genetics of head and neck tumors. Lyon: International Agency for Research on Cancer (IARC) Press; 2005. p. 306-307.

14. Woolgar JA, Rippin JW, Browne RM. The odontogenic keratocyst and its occurrence in the nevoid basal cell carcinoma syndrome. Oral Surg Oral Med Oral Pathol 1987 Dec;64(6):727-730.

15. Ahn SG, Lim YS, Kim DK, Kim SG, Lee SH, Yoon JH. Nevoid basal cell carcinoma syndrome: a retrospective analysis of 33 affected Korean individuals. Int J Oral Maxillofac Surg 2004 Jul;33(5):458-462.

16. Gupta SR, Jaetli V, Mohanty S, Sharma R, Gupta A. Nevoid basal cell carcinoma syndrome in Indian patients: a clinical and radiological study of 6 cases and review of literature. Oral Surg Oral Med Oral Pathol Oral Radiol 2012 Jan;113(1): 99-110.

17. Hyun HK, Hong SD, Kim JW. Recurrent keratocystic odontogenic tumor in the mandible: a case report and literature review. Oral Surg Oral Med Oral Pathol Oral Radiol Endod 2009 Aug;108(2):e7-e10.

18. Muzio LL, Nocini P, Bucci P, Pannone G, Procaccini M. Early diagnosis of nevoid basal cell carcinoma syndrome. J Am Dent Assoc 1999 May;130(5):669-674.

19. Barreto DC, Chimenos Kustner E. New considerations about the diagnosis of odontogenic keratocysts. Med Oral 2001 Nov-Dec;6(5):350-357.

20. Shanley S, Ratcliffe J, Hockey A, Haan E, Oley C, Ravine D, Martin N, Wicking C, Chenevix-Trench G. Nevoid basal cell carcinoma syndrome: review of 118 affected individuals. Am J Med Genet 1994 Apr 15;50(3):282-290.

21. Endo M, Fujii K, Sugita K, Saito K, Kohno Y, Miyashita T. Nationwide survey of nevoid basal cell carcinoma syndrome in Japan revealing the low frequency of basal cell carcinoma. Am J Med Genet 2012 Feb;158A(2):351-357.

22. Jones EA, Sajid MI, Shenton A, Evans DG. Basal cell carcinoma in Gorlin syndrome: a review of 202 patients. J Skin Cancer 2011;2011:217378, 1-6. 